\title{
HANS HERMANN BEHR (1818-1904): BOTANIST, ENTOMOLOGIST, ANTHROPOLOGIST, HUMORIST AND DANGEROUS?
}

\author{
by Allan H. Bretag
}

(with one text-figure and six plates)

\begin{abstract}
Bretag, A.H. 2016 (31:viii): Hans Hermann Behr (1818-1904): botanist, entomologist, anthropologist, humorist and dangerous? Papers and Proceedings of the Royal Society of Tasmania 150(1): 23-30. https://doi.org/10.26749/rstpp.150.1.23 ISSN 0080-4703. School of Pharmacy and Medical Sciences, University of South Australia, Adelaide, SA 5000, Australia. Email: bretagah@iinet.net.au

Hans Hermann Behr arrived in Adelaide in late 1844 as a newly-graduated doctor interested more in botany, entomology and anthropology. After just one year, he returned to Germany with prolific samples and notes. He returned to Adelaide towards the end of 1848, again exploring and collecting extensively. Within a year he left for the Philippines and after another year had arrived in San Francisco where he firmly established his international reputation.
\end{abstract}

Key Words: Hans Hermann Behr, South Australia, California, botany, entomology, humour.

\section{INTRODUCTION}

Hans Hermann Behr (pl. 1) was born on 18 August 1818 at Cöthen in the Duchy of Anhalt-Cöthen. After schooling in Cöthen, he studied in Halle and Würzburg before being awarded his medical doctorate from the Friedrich Wilhelm University of Berlin (now the Humboldt University) in 1843 (Kraehenbuehl 1981). Motivated by his interests other than medicine and encouraged by mentors and friends including Alexander von Humboldt and Karl Ritter, he soon left for the new colony of South Australia and arrived in Adelaide in September 1844 (Kraehenbuehl 1981). Although newly graduated as a doctor, he was, apparently, interested only in collecting plants and insects and studying the behaviours and interactions of the colonists and Aborigines. He left Adelaide in October 1845, returning to Germany by mid1846, having made prolific collections and observations on short explorations in the ranges and river flats to the immediate north and east of Adelaide (Kraehenbuehl 1981). These materials were quickly assembled for publication but, disenchanted with the social situation and his personal prospects in Cöthen, he returned to Adelaide towards the end of 1848 (Garstenauer 2015). He again collected extensively. Within a year, however, Behr had left for the Philippines (Kraehenbuehl 1981) and after another year or so had arrived in San Francisco (Behr 1891) where he firmly established his international reputation (Legge 1953).

\section{DR HANS HERMANN BEHR: A BRIEF BIOGRAPHY}

Unlike Hans Hermann Behr, who grew up in Cöthen in the Duchy of Anhalt-Cöthen, I was raised in the Zoological Park (at the time, my parents' farm) at Monarto, South Australia, located about midway between Mount Barker and Murray Bridge, $70 \mathrm{~km}$ southeast of Adelaide (fig. 1). There, as a child, I first came across Behr when my grandmother took me picking wildflowers. Strictly speaking, my introduction

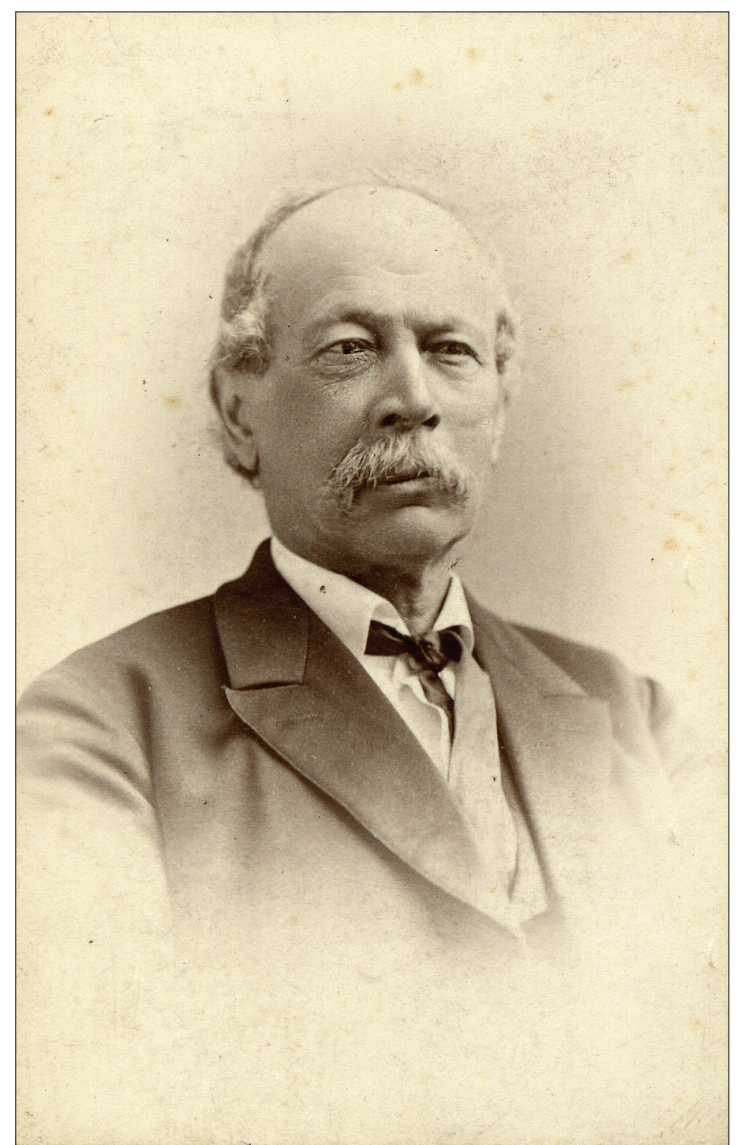

PLATE 1 - Hans Hermann Behr in about 1883. Image courtesy of the University and Jepson Herbaria Archives, University of California, Berkeley.

was to Behr's Pink Velvet Bush, Lasiopetalum behrii F. Muell., a shy, flowering shrub growing on the property; shy because its beautiful pink-faced flowers hang down, unexceptional, until lifted into view. Plate 2 shows a photograph of Behr's Pink Velvet Bush taken in 1973 in what is now the Bretag's Scrub conservation area within the Monarto Zoological 


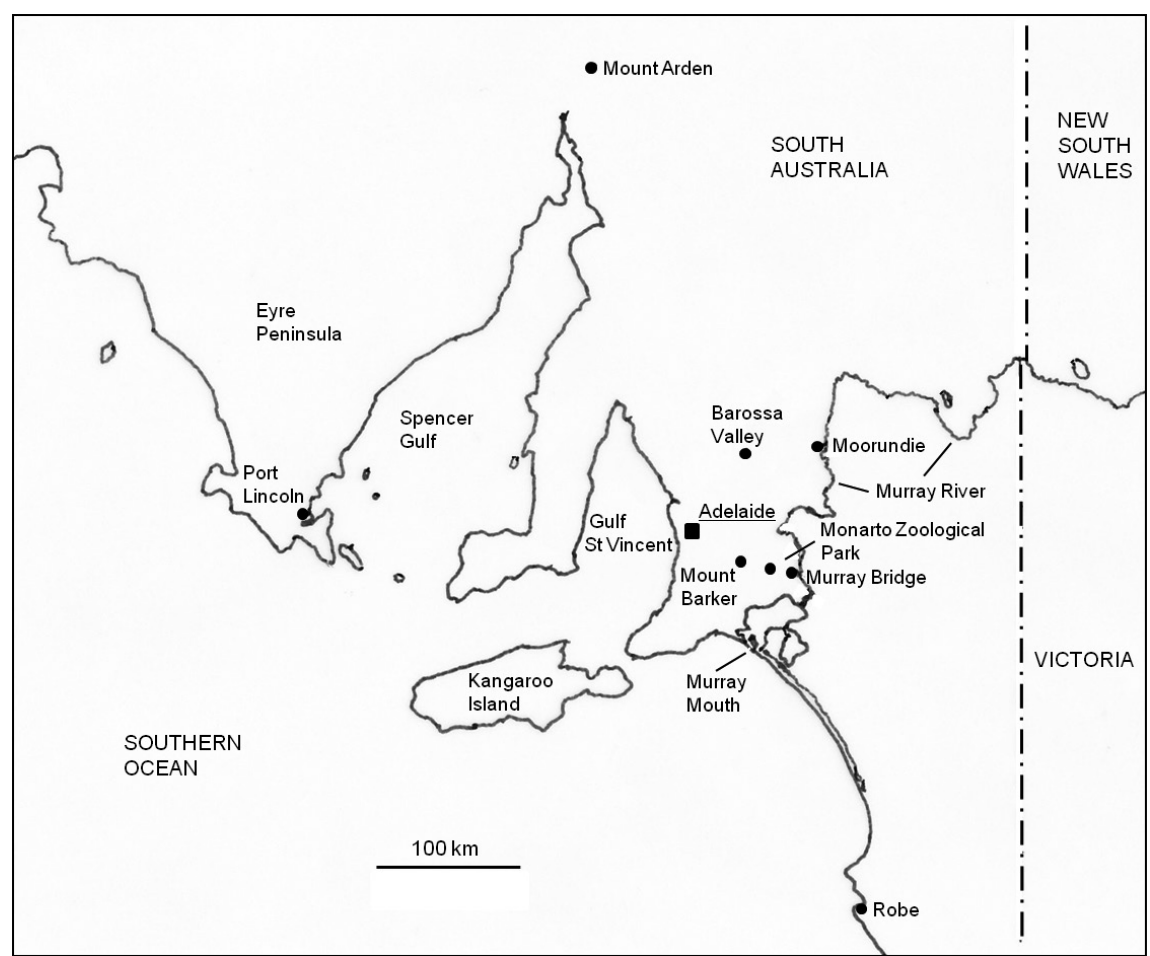

FIG. 1 - Map of southern South Australia showing places and regions where Hans Hermann Behr, Ferdinand Mueller and other German naturalists mentioned in the text, as well as, George French Angas explored and collected specimens.

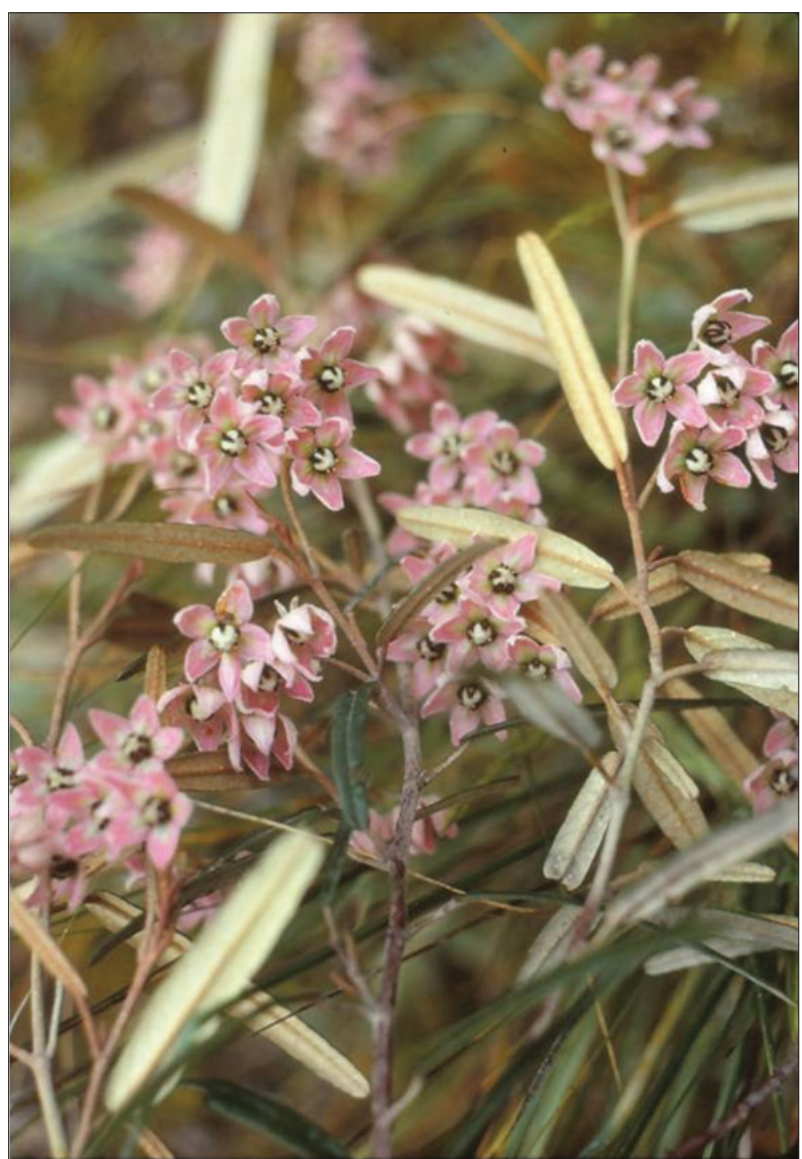

PLATE 2 - Behr's Pink Velvet Bush, Lasiopetalum behrii F. Muell. photographed by Allan Bretag in 1973 in Bretag's Scrub (now part of the Monarto Zoological Park), Monarto South, South Australia.
Park. According to Ferdinand Mueller's formal description, this plant was found "In the Mallee Scrub on the Murray River and St. Vincent's Gulf, where it was first observed by Dr. H. Behr" (Mueller 1855, p. 36).

After arriving in South Australia on the George Washington on 12 September 1844, Behr centred his activities in and near the Barossa Valley and its prominent German settlement at Tanunda (especially at nearby Bethanien) (Kraehenbuehl 1981). From there his exploratory and collecting excursions took him generally within $100 \mathrm{~km}$ to the north and east of Adelaide, between Gulf St Vincent and the Murray River. He collected plants as early as November/December 1844 from the upper regions of the Torrens and Onkaparinga rivers and from the Mount Barker region, near Hahndorf (Schlechtendal 1847) and reported climbing Mount Barker (fig. 1), southeast of Adelaide (Behr 1847). Exactly how far south he explored is uncertain although some of his accounts suggest that he could have visited the area near the Murray mouth (fig. 1) (Behr 1848a, b).

In two anthropological papers that he presented to the Berlin Geographical Society, for example, he describes his interactions with Aborigines and observations on their corroborees, their language and their beliefs (Behr 1848a, b). Unlike many general views and opinions from his time, he considered their corroborees to be akin to church services and their language to be complex, but he was critical of their morality (there is no right or wrong, only instinctive reactions to immediate circumstances with no underlying moral code of behaviour). With a certain amount of naïve, Eurocentric arrogance, he placed them at the lowest level of human development, although he did attribute this to their geographical situation. On the other hand, he conceded that the Aborigines living in the region of the Murray mouth had a religious belief in a higher being and in a life after 
PLATE 3 - Pair of Mistletoe Moths, Comocrus behri (Angas, 1847), mating. Image: courtesy of Eileen Collins, Chiltern, Victoria.

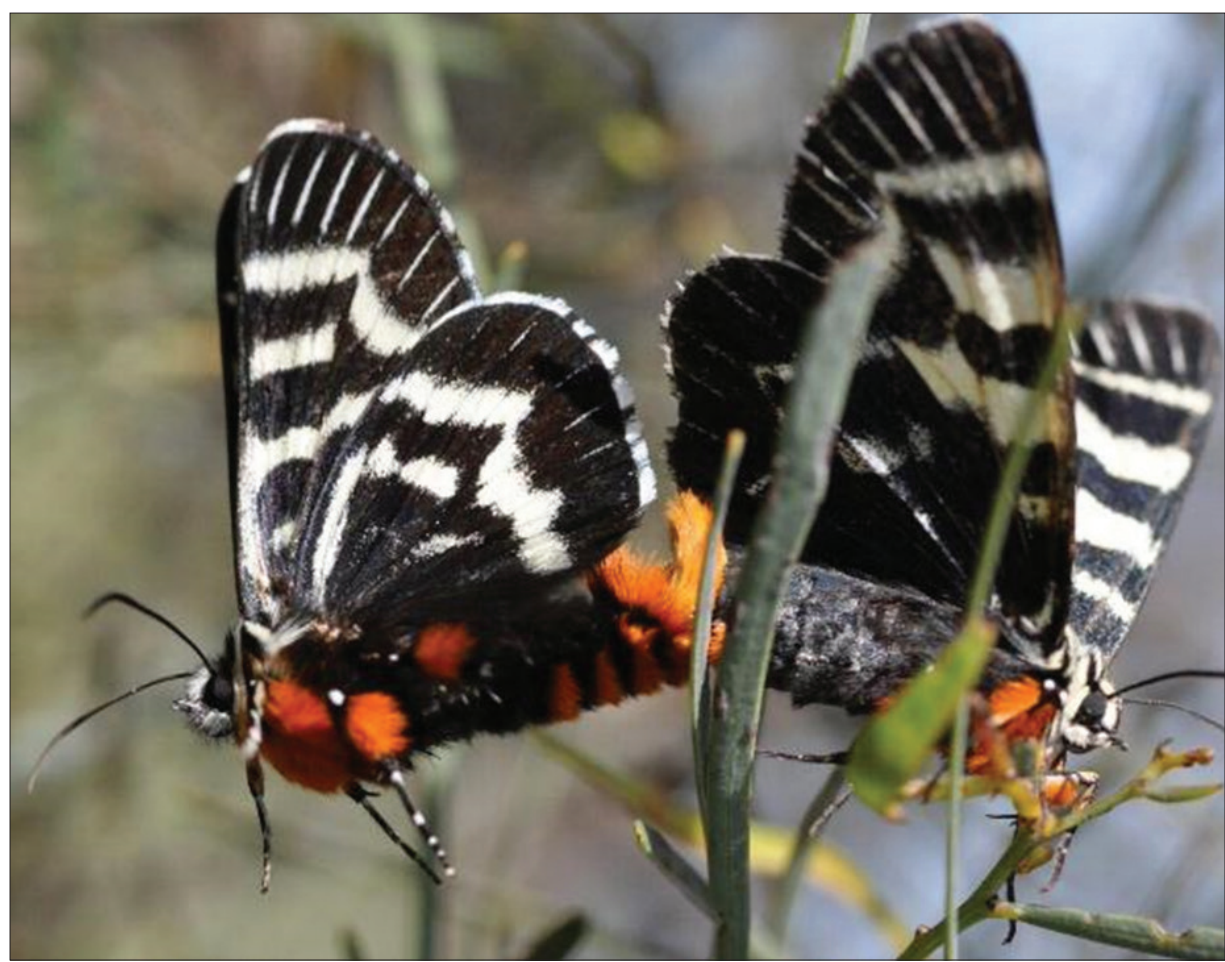

death. Whether this came from personal observations of the southern coastal Aborigines, or not, is uncertain. What is certain, however, is that on 9 October 1845, Behr left Adelaide on board the Heerjeebhoy Rustomjee Patel to make his way home to Cöthen via Java and the Cape of Good Hope (Kraehenbuehl 1981).

During this first visit to Australia he must have met George French Angas, son of George Fife Angas who played a large role in the founding of South Australia as a colony (Anon 2016a). Behr collected on and around land owned by George Fife Angas at Angas Park (present-day Nuriootpa) and Angastown (present-day Angaston) in the Barossa Valley (Schlechtendal 1847). Both Behr and George French Angas were in South Australia in the first half of 1845. Angas, himself a naturalist, an explorer and also an artist, seems to have been sufficiently impressed by Behr to have awarded him among the first published honours in a species name for the strikingly beautiful Mistletoe Moth, Comocrus behri (Angas, 1847), originally illustrated and named Agarista behri by Angas (pl. 3) (Angas 1847). In the legend to Plate XLVIII of his folio, South Australia Illustrated, Angas acknowledged the contribution to entomological science made by Behr and a number of other residents "in the Province of South Australia for the addition of many new species" (Angas 1847).

From 1847 onwards, Behr, then back in Cöthen, together with the German experts to whom he had passed his South Australian specimens, also began to publish formal descriptions of many of the new species of plants and insects he had brought back with him. Examples come from the approximately 140 specimens of Lepidoptera that Behr gave to Johann Christoph Friedrich Klug in Berlin (Klug 1850), from the unknown number of beetles left with Ernst Friedrich Germar in Halle and from well over 200 plants provided to Diederich Franz Leonhard von Schlechtendal also in Halle (Schlechtendal 1847, 1848). Some of these also honoured Behr.

As new Lepidopteran species, Klug described the Orange Sun Moth, Synemon nais Klug, 1850, and the Pale Sun Moth, Synemon selene Klug, 1850. Although Klug's paper only appeared in print in 1850 it was read before the Academy of Sciences in Berlin in May 1848 and was published as part of the Proceedings of the Academy from 1848 (Klug 1850). Interestingly, the Pale Sun Moth was later described as Synemon adelaida Swinhoe, 1892 (Swinhoe 1892), geographically appropriate but not accepted due to Klug's precedence.

Of the plant specimens treated by Schlechtendal, about 70 were considered to be new species, for example, Prostanthera behriana Schltdl. (Schlechtendal 1847). This pale flowering Downy Mintbush is somewhat similar to the extremely rare Monarto Mintbush, the bright-purple flowering Prostanthera eurybioides F. Muell. illustrated here (pl. 4).

The Darkling Beetle (pl. 5), Cardiothorax behri (Germar, 1848) is one of the many insect specimens collected by Behr and was formally described as "Prosodes? Behrii" by Germar (1848).

By early 1848, Behr had developed a deep sympathy for, and was beginning to become involved in, the revolutionary movements for political and social reform sweeping Europe. His employment prospects as a young doctor were diminishing in Cöthen, perhaps partly due to his increasingly radical views and partly due to growing competition from Christian Friedrich Samuel Hahnemann's "Homeopathy" that had been uniquely and especially nurtured and protected in Cöthen by the Duke Friedrich Ferdinand of Anhalt-Cöthen (Garstenauer 2015). Hahnemann had termed conventional medicine "Allopathy" 


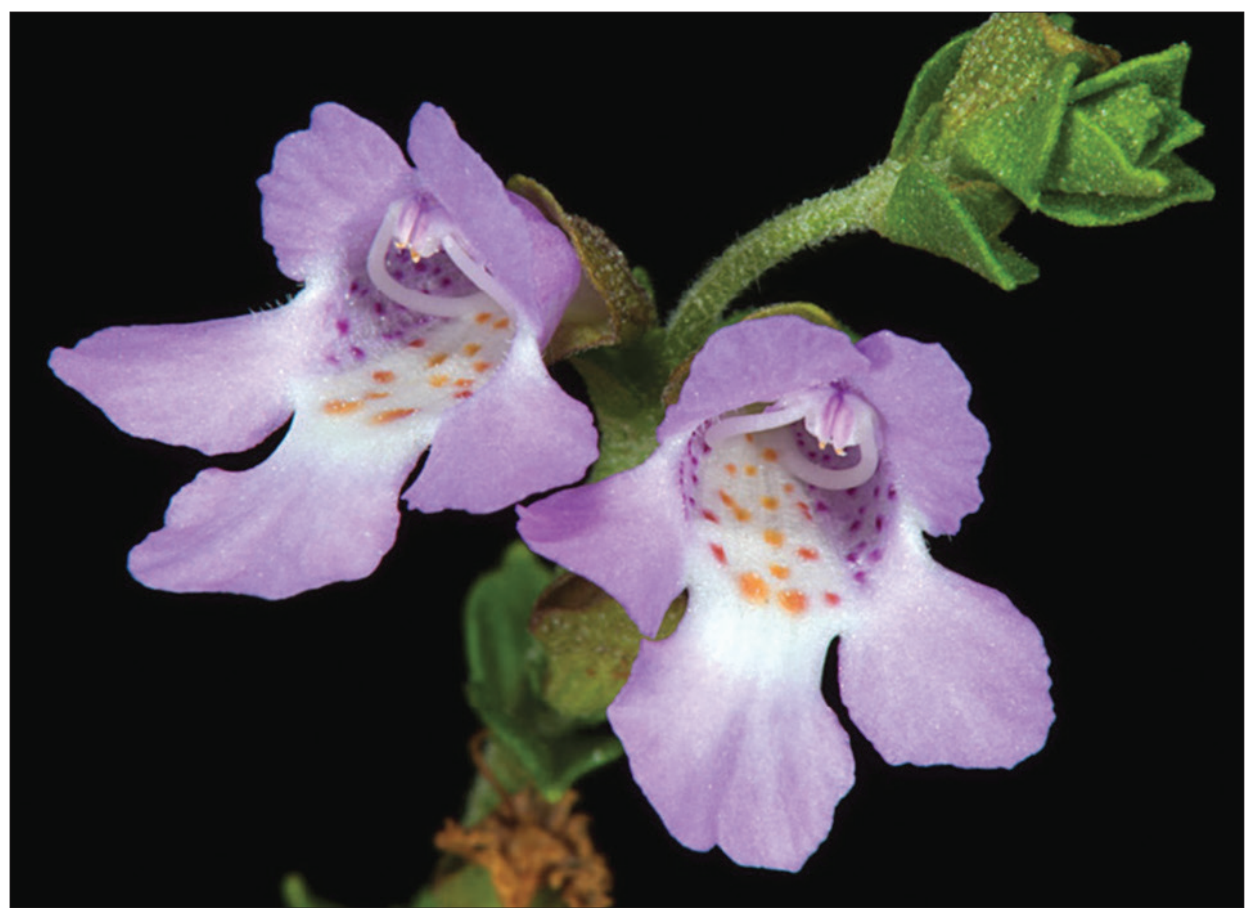

PLATE 4 - Brightly coloured flowers of the extremely rare Monarto Mintbush, Prostanthera eurybioides F. Muell. Image courtesy of John Boland, Adelaide, South Australia. and warned against its dangers. In any case, by May 1848 Behr was on his way back to Adelaide.

Meanwhile, on 15 December 1847, Dr Ferdinand Mueller and Ferdinand Osswald (both pharmaceutical chemists with particular interests in botany) had arrived in Adelaide on the Hermann von Beckerath (Anon 1847) whereupon Mueller undertook his first employment in the German chemist shop of Büttner and Heuzenroeder, Chemists and Druggists (Anon 1896) (in operation from January 1846 until the dissolution of their partnership in January 1849) (Anon 1849a). Joseph Hieronymus Moritz Heuzenroeder had arrived on the Heerjeebhoy Rustomjee Patel on 18 September 1845 (Anon 1845) and was himself an avid collector of the plants and insects of the new colony (Jones 2011). As mentioned above, it was just three weeks later that Behr ended his first stay in South Australia, leaving on the same ship.

In the year leading up to Behr's arrival on his second visit to South Australia (in November 1848), Osswald was collecting around the Barossa Valley and in the South East district of the state, near Robe (Kraehenbuehl 1981). Osswald seems to have taken over the German chemist shop in Rundle Street in 1849 because Dr William Hillebrand (see below) advertised on 21 April 1849 that he would consult from there "every morning till 11 o'clock" (Anon 1849b).

Ferdinand Mueller, too, was collecting and exploring further north during 1848, up to Mount Arden in the Flinders Ranges area (fig. 1). He had also purchased a small property at Bugle Ranges south of Mount Barker (fig. 1), some $30 \mathrm{~km}$ southeast of Adelaide (Anon 1896). It is likely that at about this time Mueller collected, or was supplied with, a specimen of the very rare Monarto Mintbush, Prostanthera eurybioides (pl. 4). Because of its extremely restricted geographical range, there is a very good chance it was found in the Mallee Scrub within, or neighbouring, the Monarto Zoological Park (in accord with Mueller's 1855 description, illustrated and mentioned above) (Mueller 1855).

Back in South Australia again, arriving on the Victoria on 6 November 1848, Behr once more collected around the Barossa Valley and east to the River Murray (Kraehenbuehl 1981). An eloquent account of his observations on an excursion made to "Maronde" [= Moorundie], south of the present-day Blanchetown, has been published in translation (Kraehenbuehl 1981). The recipients of Behr's 1848-49 collections are uncertain although, in a note relating to a letter sent by Behr from Manila in December 1849, it is suggested that his plant specimens may have been sent to William Jackson Hooker at Kew in the United Kingdom (Anon 1850).

Dr Wilhelm (William) Hillebrand (physician) and Carl Wilhelmi (seedsman), fellow Germans with a zeal for botanical collecting, arrived in Adelaide in March 1849 on the Godeffroy (see below), Hillebrand subsequently exploring the southern Mount Lofty Ranges to Lake Alexandrina. Wilhelmi covered much the same area as that investigated by Hillebrand and Behr before turning his attention west to the Port Lincoln area on Eyre Peninsula and then to the South East district of the state (Jones 2011, Anon 2016b).

It seems most likely that these Germans and others already in South Australia (Jones 2011) would have met and known each other, and even explored and collected together at times, although evidence is scant (Kraehenbuehl 1981) and at times unreliable. For example, Meier (Meier 2005a, p. 8) has written:

When the Godeffroy made Port Phillip, South Australia [actually, Port Phillip is in Victoria], on February 10, 1849, she could boast about having sailed from Plymouth to Australia in ninety-four days. Hardly off 
PLATE 5 - Darkling Beetle, Cardiothorax behri (Germar, 1848). Image courtesy H. De Graaf, (SARDI), Adelaide, South Australia.

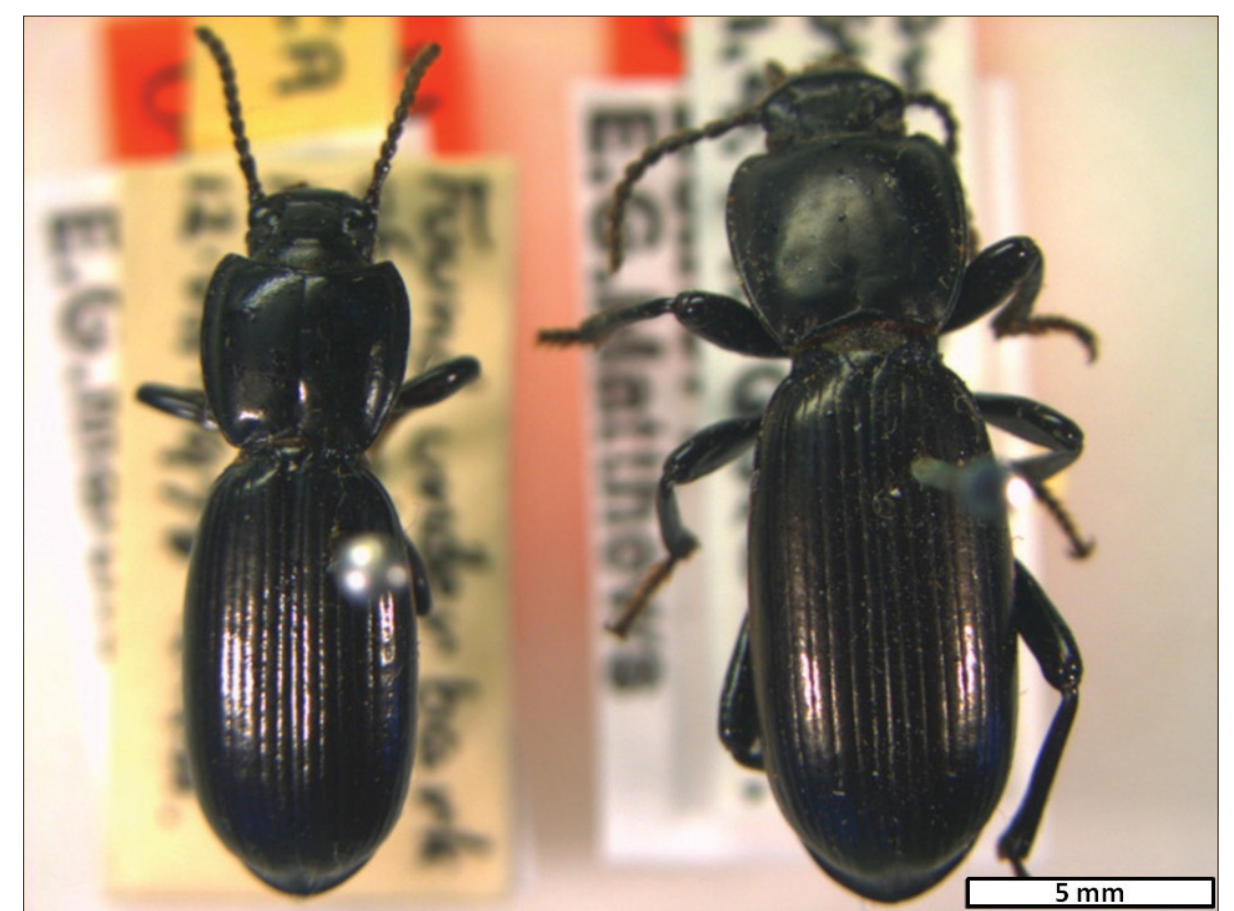

the boat and still overwhelmed by their impressions of the new continent, Hillebrand and fellow botanists Otto Boesewetter and J.F.C. Wilhelmi, who had traveled with him from Germany, met in Ferdinand Mueller's Melbourne home ... Mueller introduced him [Hillebrand] to Hans Hermann Behr.

Actually, shortly after arriving at Port Phillip, the Godeffroy sailed on to Port Adelaide, South Australia, arriving on 1 March (Anon 1849c). While there is no evidence that Boesewetter travelled on to Port Adelaide, Hillebrand and Wilhelmi definitely did (Anon 1849c) and, actually, Mueller's home at the time was in Adelaide, South Australia (Anon 1896), and not Melbourne, Victoria, so if these botanists met immediately after their arrival, it would have been in Adelaide.

Behr and Hillebrand left Adelaide together in spring 1849 travelling on to the Philippines (Kraehenbuehl 1981, Anon 1850). It is uncertain exactly when and how they left Adelaide, but one possibility is that they sailed on the Wilhelmine Marie that left Port Adelaide on about 22 September 1849 bound for Manila (Anon 1849d). They had arrived in Manila by 12 December 1849 when they both applied for physician's licences (Garstenauer, W., University of Vienna, pers. comm. 2015). Neither Behr nor Hillebrand remained long in the Philippines. Behr's departure date from Manila is unknown but by late September 1850 he was in San Francisco (Behr 1891). Hillebrand left on 11 September 1850 on the Naumkeang, arrived in San Francisco on 29 November (Meier 2005b) and by 22 December he had reached Honolulu (Greer 1969). No plant or insect collections made by Behr or Hillebrand in the Philippines are known to exist (Krahenbuehl 1981).

In California, Behr became famous in several fields, most of which were not well-rewarded financially so that he was obliged to practise as a physician. Soon after his arrival there were major outbreaks of cholera in San Francisco and Sacramento. Not much later, a notorious gang of Australian ex-convicts, the "Sydney Ducks", were accused of robbery, extortion and widespread arson. A store in central San Francisco was set on fire in mid-1851 leading to some 2000 surrounding buildings being destroyed in the resultant conflagration (Anon 2016c). In that year Behr became a member of the San Francisco Vigilance Committee, outside the law, that hanged several of the criminals and drove the remnants out of town. His scientific training and expertise soon led him to join the fledgling California Academy of Sciences (1854) (Gutzkow et al. 1905), being made curator of the Entomology Department for varying periods beginning in 1862 (Anon 2016d). He was later appointed as the Foundation Professor of Botany at the California College of Pharmacy (1872) (Legge 1953) and was elected to membership of the Bohemian Club of San Francisco (1873) (Legge 1953).

By 1882 his collection of Lepidoptera had grown to nearly 20000 specimens through his own long-term and ardent collecting and international exchanges (Anon 1882). On these, he had written numerous papers (the Royal Society of London's Catalogue of Scientific Papers shows 10 published between 1863 and 1870, and see also Legge (1953)) and had himself formally described many new species (e.g., Behr 1870). Presumably, his collection had grown considerably larger by the time of his death in 1904. Unfortunately, this outstanding collection and Behr's personal papers were all lost, with a single known exception, along with most of the California Academy of Sciences Museum's mammal, bird, insect and plant specimens in the disastrous fire following the 1906 San Francisco earthquake (Leviton \& Aldritch 1997, Moran 2013). Rediscovered in 2013, the single surviving book that had originally belonged to Behr was 
a folio of ornithological illustrations which, according to its inscription, he had presented to the museum director, Leverett M. Loomis, in 1901. The first plate in the folio retains the handwritten signature, "Property of H.H. Behr Dr" (Moran 2013).

Apart from his renowned scientific works, Behr was also an accomplished writer of fiction in English and German, often humorous, from novels, short stories and verse to "jinks", these last being short speeches to the San Francisco Bohemian Club that were collected and published posthumously as Hoot of the Owl (Behr 1904). In one of the many memorable examples of these, he writes that he was admonished to be virtuous and become happy by his aunt who was "an elderly lady, not exactly prepossessing in her exterior, but shockingly virtuous and as unmarried as possible". She drank valerian tea with a dash of ether in it, wore green spectacles, "always felt miserable and respectable, and between asafoetida and valerian led a most unhappy life". Behr, nevertheless, decided "to give virtue a fair shake" and subsequently tried many virtues in moderation but concluded that the happiest moment of his life was when he "dropped virtue altogether". In another instance, he says he was asked to make a presentation to his fellow Bohemians on ethnology, but being unsure of whether they meant entomology, he wrote:

At first I intended to follow the custom of my fellowscientists - that is, to compile an ethnological or

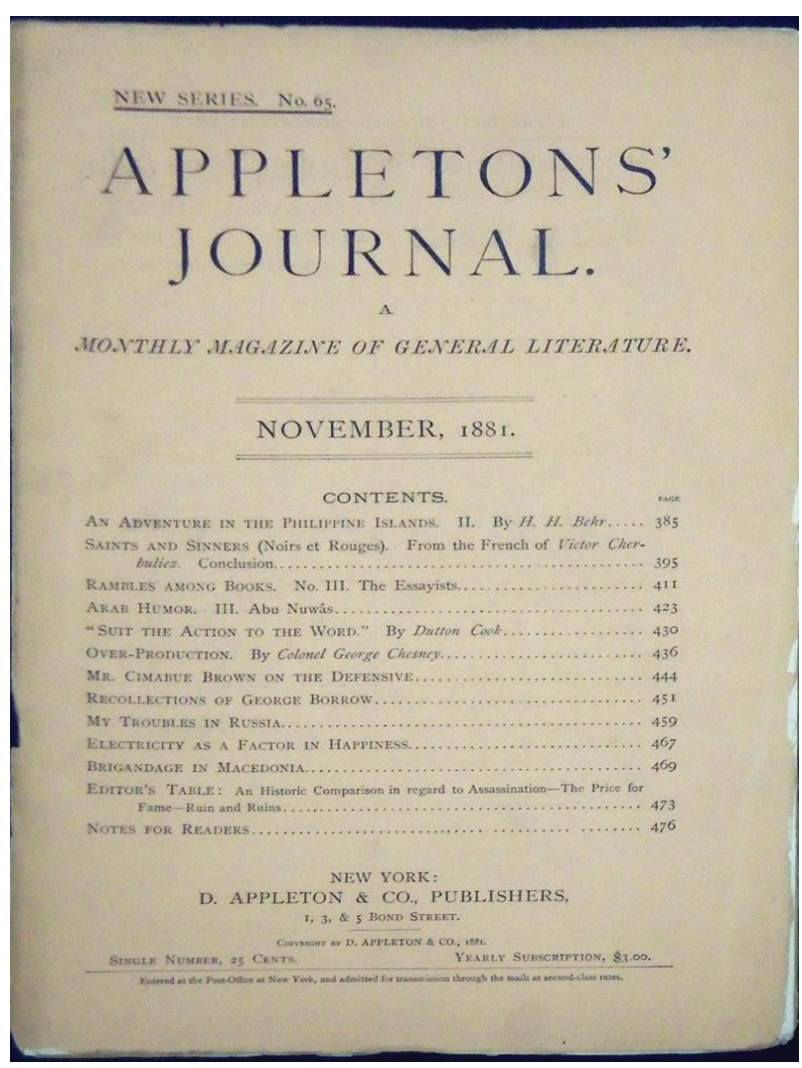

PLATE 6 - Cover of Appletons' Journal for November 1881 with its Contents showing "An Adventure in the Philippine Islands II" by H.H. Behr. entomological paper of plagiarisms, in which only the errors are my own; but, on more mature reflection, I thought, as Alexander von Humboldt is dead ..., I would not run the slightest risk to be discovered in drawing from my own bold and lively imagination.

(Behr 1904, pp. 101-102)

Under the pseudonym, "Ati Kambang", he also wrote a three-volume novel largely set in South Australia, Auf fremder Erde (Kambang 1864), utilising humour in describing the behaviours and interactions between the various ethnic immigrant groups and the Aborigines. $\mathrm{He}$ provides astute observations of these people's religions and superstitions in the light of the scientific knowledge of the time (Garstenauer 2013). Another novel, Dritte Söhne, about California, was published in instalments in a German-language Californian newspaper, but apparently only fragments remain (Garstenauer, W., University of Vienna, pers. comm. 2015).

In the story, "An Adventure in the Philippine Islands", published in the October and November 1881 issues of the New York Literary Magazine, Appletons' Journal (pl. 6) (Behr 1881a, b), he wrote of himself (possibly with at least a grain of autobiographical truth), "I was young, a socialist, and emancipation-mad in different directions", and, "In the glorious year of 1848 I had been guilty of all sorts of misdemeanours, [and] looked upon myself as a very dangerous kind of person" (Garstenauer 2013, pp. 56-63, Behr 1881a, p. 339).

Behr has been described as an amiable fellow and a genial host but also as rather weird and hot-tempered (Kraehenbuehl 1981, Garstenauer 2015, Meier 2005b). Apart, perhaps, from some early flirtations with radicalism and his later membership of the San Francisco Vigilance Committee, none of this suggests that Behr really was a dangerous person. His observations of the devastating effects of human activity in building cities and expanding agriculture (Behr 1847) and of the inadvertent introduction of invasive species such as Milk Thistles Silybum marianum (L.) Gaertn. and Water Buttons Cotula coronopifolia L. in both South Australia and California (Behr 1891), indicate that he was deeply aware of ecological and environmental damage. Nevertheless, he himself seems to have been involved in the introduction of Australasian White Mangroves Avicennia marina subsp. australasica (Walp.) J.Everett (Legge 1953) and various Eucalypts (Santos 1997) to California. Definitely not benign, the subsequent weedlike proliferation of these species has proven that this was probably his most dangerous action.

\section{CONCLUSIONS}

Overall, Behr made an exceptional, but no longer sufficientlyrecognised, contribution to the early knowledge of South Australian and Californian plant and insect species. Although he was an accomplished linguist, perhaps due to the short time that he spent in South Australia, his interactions with, and observations of, the local Aborigines were hindered 
by communication difficulties making his accounts of them seem somewhat amateurish. His best contributions to ethnology came in his depictions of immigrant and indigenous South Australians in his humorous novel, Auf fremder Erde. Behr's later academic involvement with the California Academy of Sciences and the California College of Pharmacy was outstanding. His alma mater, the Friedrich Wilhelm University of Berlin, recognised all of this when it honoured and feted him on the occasion of his 80th birthday with the award of the honorary degree of "Doctor Honoris Causa” on 18 August 1898 (Anon 1904).

\section{ACKNOWLEDGEMENTS}

I particularly want to acknowledge the late Margaret Kenny of the South Australian Museum who formally introduced me to Lasiopetalum behrii in 1973, thereby triggering my subsequent search for information about Behr. Darrell Kraehenbuehl's detailed account of Behr's two visits to South Australia was particularly informative, helping me to track down much of Behr's early botanical, entomological and anthropological work. I have also been greatly assisted by Werner Garstenauer of the University of Vienna with respect to Behr's political views, his travels to and from the Philippines and his fictional and ethnographic publications.

\section{REFERENCES}

Angas, G.F. 1847: South Australia Illustrated. Thomas McLean, London: Part 7, plate 37.

Anon. 1845: South Australian Register, 23 September, p. 2.

Anon. 1847: South Australian Register, 18 December, p. 4.

Anon. 1849a: South Australian Register, 3 January, p. 2.

Anon. 1849b: Adelaide Observer, 21 April, p. 1.

Anon. 1849c: South Australian Register, 3 March, p. 4.

Anon. 1849d: South Australian Register, 22 September, p. 4.

Anon. 1850: Reisende. Botanische Zeitung 8: 335.

Anon. 1882: 'A Fine Collection of Butterflies', New York Times, 25 December 1882 [Headline].

Anon. 1896: South Australian Register, 12 October, p. 7.

Anon. 1904: Dr. Hans Herman Behr. Entomological News 15: 142-144.

Anon. 2016a: George French Angas, https://en.wikipedia.org/wiki/ George_French_Angas (accessed 25 January 2016).

Anon. 2016b: Council of Heads of Australasian Herbaria: Biographical Notes, https://www.anbg.gov.au/biography/ wilhelmi-carl.html (accessed 25 January 2016).

Anon. 2016c: Timeline San Francisco to 1892, http://www.timelines. ws/cities/SF_A_1892.HTML (accessed 25 January 2016).

Anon. 2016d: California Academy of Sciences: Entomology Collection, http://www.calacademy.org/scientists/ entomology-collection (accessed 25 January 2016).

Behr, H.H. 1847: Ueber die Verhältnisse der südaustralischen Flor im Allgemeinen. Linnaea 20: 545-558.

Behr, H.H. 1848a: Über die Urbewohner von Adelaide in Süd-Australien nach eigenen Anschauungen,während seines dortigen Aufenthalts. Monatsberichte über die Verhandlungen der Gesellschaft für Erdkunde zu Berlin 5: 82-93.

Behr, H.H. 1848b: Über die aussern Verhältnisse, welche auf die Entwickelung der Australier eingewirkt haben. Monatsberichte über die Verhandlungen der Gesellschaft für Erdkunde zu Berlin 5: 145-149.
Behr, H.H. 1870: Synopsis noctuidarum hucusque in California repertarum. Transactions of the American Entomological Society 3: 23-28.

Behr, H.H. 1881a: "An Adventure in the Philippine Islands. I". Appletons' Journal: A Magazine of General Literature: $339-347$.

Behr, H.H. 1881b "An Adventure in the Philippine Islands. II". Appletons' Journal: A Magazine of General Literature, November: 385-395.

Behr, H.H. 1891: Botanical reminiscences. Zoe 2: 2-6.

Behr, H.H. 1904: The Hoot of the Owl Robertson, San Francisco.

Garstenauer, W. 2013: South Australia als Ort von Wissenstradierung und Selbstbefragung im Zeichen des Komischen bei Hans Hermann Behr. In F.-J. Deiters, A. Fliethmann, B. Lang, A. Lewis and C. Weller (eds) Limbus. Australisches Jahrbuch für germanistische Literatur- und Kulturwissenschaft/Australian Yearbook of German Literary and Cultural Studies. Rombach, Freiburg i.Br 6: Topos Australien, pp. 123-140.

Garstenauer, W. 2015: Politische Erinnerung als Unterhaltung: Die 1848er-Revolution bei Hans Hermann Behr. In A. Millner (ed.) Empörung! Besichtigung einer Kulturtechnik WUV, Vienna: pp. 55-74.

Germar, E.F. 1848: Beiträge zur Insektenfauna von Adelaide. Linnaea Entomologica 3: 153-247.

Greer, R.A. 1969: The founding of the Queen's Hospital. The Hawaiian Journal of History 3: 110-145 (Footnote 76, pp. 137-141).

Guztkow, F., Chismore, G. \& Eastwood, A. 1905: Doctor Hans Herman Behr: born August 18, 1818-died March 6, 1904. California Academy of Sciences, San Francisco.

Jones, P. 2011: Colonial Wissenschaft: German naturalists and museums in nineteenth-century South Australia. In P. Monteath (ed.) Germans: Travellers, Settlers and Their Descendants in South Australia. Wakefield Press, Kent Town: pp. 204-236.

Kambang, A. [pseudonym for H.H. Behr] 1864: Auffremder Erde. Eine Roman. Mit einem Vorwort von Friedrich Gerstäcker. [3 Vols] Costenoble, Jena.

Klug, J.C.F. 1850: Über die Lepidopteren-Gattung Synomen. Abhandlungen der Königlichen Akademie der Wissenschaften $z u$ Berlin Aus dem Jahre 1848: 245-257.

Kraehenbuehl, D.N. 1981: Dr H.H. Behr's two visists to South Australia in 1844-45 and 1848-49. Journal of the Adelaide Botanic Gardens 3: 101-123.

Legge, R.T. 1953: Hans Herman Behr: German Doctor, California Professor and Academician, and "Bohemian". California Historical Society Quarterly 32: 243-262.

Leviton, A.E. \& Aldrich, M.L. 1997: Theodore Henry Hittell's The California Academy of Sciences 1853-1906. California Academy of Sciences, San Francisco: p. 471 et seq.

Meier, U.H. 2005a: Hawaii's Pioneer Botanist: Dr. William Hillebrand, His Life \& Letters. Bishop Museum, Honolulu: p. 8.

Meier, U.H. 2005b: Hawaii's Pioneer Botanist: Dr. William Hillebrand, his Life \& Letters. Bishop Museum, Honolulu: p. 11.

Moran, B. 2013: Mystery in the Stacks, Part II, https://www. calacademy.org/blogs/from-the-stacks/mystery-in-thestacks-part-ii (accessed 25 January 2016).

Mueller, F. 1855: Art. IV. Definitions of rare or hitherto undescribed Australian Plants, chiefly collected within the Boundaries of the Colony of Victoria, and examined by Dr. Ferd. Mueller. (Continued.). Transactions of the Philosophical Society of Victoria 1: 34-50.

Santos, R.L. 1997: The Eucalyptus of California: Seeds of Good or Seeds of Evil? Alley Cass, Denair California: Section One.

Schlechtendal, D.F.L. 1847: Bestimmung und Beschreibung der von Dr. Behr in Südaustralien gesammelten Pflanzen. Linnaea 20: 559-672. 
Schlechtendal, D.F.L. 1848: Nachtrag zu den Südaustralischen

Pflanzen des Hrn. Dr. Behr. Linnaea 21: 444-452.

Swinhoe, C. 1892: Catalogue of eastern and Australian Lepidoptera Heterocera in the collection of the Oxford University Museum. Clarendon Press, Oxford: Part 1, Plate 7, Figure 10.

(Accepted 3 May 2016) 